\title{
Effects of Repeated Growing Season Prescribed Fire on the Structure and Composition of Pine-Hardwood Forests in the Southeastern Piedmont, USA
}

\author{
Matthew J. Reilly ${ }^{1,2, *}$, Kenneth Outcalt ${ }^{2}$, Joseph J. O'Brien ${ }^{2}$ and Dale Wade ${ }^{2}$ \\ 1 Department of Forest Ecosystems and Society, College of Forestry, Oregon State University, Corvallis, \\ OR 97330, USA \\ 2 USDA Forest Service, Southern Research Station, Athens, GA 30602, USA; koutcalt@fs.fed.us (K.O.); \\ jjobrien@fs.fed.us (J.J.O'B.); pyrowade@gmail.com (D.W.) \\ * Correspondence: matthew.reilly@oregonstate.edu; Tel.: +1-541-758-7759 \\ Academic Editor: Timothy A. Martin \\ Received: 24 October 2016; Accepted: 21 December 2016; Published: 26 December 2016
}

\begin{abstract}
We examined the effects of repeated growing season prescribed fire on the structure and composition of mixed pine-hardwood forests in the southeastern Piedmont region, Georgia, USA. Plots were burned two to four times over an eight-year period with low intensity surface fires during one of four six-week long periods from early April to mid-September. Density of saplings $(0.25-11.6 \mathrm{~cm}$ diameter at breast height) was significantly reduced after one or two fires during the first four-year period. Sapling density declined with additional burning over the next four years, but density of mesic hardwoods including sweetgum (Liquidambar styraciflua) and red maple (Acer rubrum) remained relatively high $\left(\sim 865\right.$ stems ha $\left.^{-1}\right)$. Repeated burning had little effect on density or basal area of trees $(\geq 11.7 \mathrm{~cm} \mathrm{dbh})$ and changes in overstory structure were limited to small increases in the quadratic mean diameter of all trees and pines. We found little evidence to suggest differential effects on structure or composition due to timing of burn within the growing season. Although repeated growing season burning alters midstory structure and composition, burning alone is unlikely to result in immediate shifts in overstory composition or structure in mixed pine-hardwood forests of the southeastern Piedmont region.
\end{abstract}

Keywords: prescribed fire; season of burn; southeastern Piedmont; growing season burn; pine-hardwood forests

\section{Introduction}

Prescribed fire is an important tool for management and restoration of forests around the world [1-7]. The objectives of prescribed fire are diverse and vary among forest ecosystems, but often include manipulation of stand structure to decrease hazardous fuels [7], increase diversity and productivity in the understory [8], and promote open habitat conditions [4]. Responses to prescribed fire also vary among forested ecosystems depending on productivity, species composition, and topography [9]. Accordingly, region specific information is required to provide guidelines and inform managers on the potential outcomes of prescribed fire as a landscape process [10].

The effects of prescribed fire usually include reductions in basal area and density, but can vary among species with different life history traits (i.e., re-sprouters vs. obligate seeders), as well as among seasons due to differences in phenology and fire intensity [11]. In most cases, growing season burns are considered more effective at reducing woody vegetation than dormant season burns [11-14]. Less is known about how the effects of prescribed fire differ due to variation in timing of application within the growing season, and there is little consensus among studies from different ecosystems [13-18]. Furthermore, there is evidence supporting variable response among species 
within a single ecosystem $[14,18]$. There is some evidence that hardwoods are more sensitive to early growing season fires, potentially because root carbohydrate stores may be reduced following leaf production [13,14]. Pines (Pinus spp.) are sometimes thought to be more susceptible to late growing season fire, but results are mixed $[14,19]$. Thus, few generalizations are available to support management across a wide range of forest ecosystems.

In the southeastern United States, more land is treated with prescribed fire than the rest of the U.S. combined [4]. Despite a long history of research on prescribed fire in the Coastal Plain and Southern Appalachian Mountain regions [19-21], there is little recent work in the Piedmont region where prescribed fire is an important management practice on federal forest lands. The objectives of prescribed fire on federal lands in the Piedmont region generally include thinning shrubs and hardwood saplings [5], increasing diversity in the understory [6], and promoting habitat for the endangered red cockaded woodpecker (Picoides borealis Vieillot). Red cockaded woodpeckers require frequent fire to maintain open stands [22-24] and will abandon colonies if midstory density gets too high [25].

Most information on the effects of fire in the Piedmont region dates back to the 1950s and 1960s when prescribed fire was used as a silvicultural tool to reduce hardwood competition in loblolly pine (Pinus taeda L.) stands [26-29]. Many of these early studies showed that single or a few repeated burns result in a temporary reduction of hardwoods, but some suggest that the net result is typically an increase in hardwoods a few years following a burn [30,31]. However, long-term studies on repeated fire in the Piedmont region are limited [32]. Thus, managers must draw from studies in the Coastal Plain region where variables such as fuels, burning conditions, and species composition often differ drastically.

We compared effects of repeated growing season prescribed fires on the structure and composition of mixed pine-hardwood forests in the southeastern Piedmont, Georgia, USA. Twenty-four plots were burned two to four times with low intensity surface fires over an eight-year period during one of four six-week long periods from early April to mid-September. We address the following questions:

(1) How do the density and composition of saplings in the midstory change following repeated growing season burns?

(2) How do the structure (i.e., basal area, density, and quadratic mean diameter) and composition of overstory trees change following repeated growing season burns?

(3) How do the effects of repeated growing season burns on overstory and midstory structure and composition differ when fires are applied at different times within the growing season?

\section{Materials and Methods}

\subsection{Study Site}

The 13,355 ha Piedmont National Wildlife Refuge (PNWR) is located in central Georgia near the Ocmulgee River in Jones County, approximately 40 kilometers north of Macon (Figure 1). Elevations range from a low of $100 \mathrm{~m}$ in creek bottoms to a high of $205 \mathrm{~m}$ on upper ridges. Most of the refuge is on severely eroded former agricultural land that was abandoned in the early 1900s. The average annual rainfall is approximately $115 \mathrm{~cm}$ and occurs fairly evenly throughout the year, but short (several weeks) dry spells are common in the summer, with more extended droughts occurring every decade or so [33]. The growing season extends from April to October. Temperature maximums average about $15{ }^{\circ} \mathrm{C}$ during the winter to above $32{ }^{\circ} \mathrm{C}$ in the summer. Soils are primarily Davidson clay loams [34].

There is little information available on historical fire regimes in the Piedmont region. Cowell [35] used historical land-survey data from the early 19th century and suggested a historical fire return interval from 20-50 years, but Guyette et al. [36] predict a much lower frequency of 2-4 years based on climate and physical chemistry of fuels. The PNWR instituted a 4-year winter burn schedule in the 1960s to improve wildlife habitat on upland pine sites. Within the past two decades, the refuge started to burn many sites on a 3-year rotation, primarily for red-cockaded woodpecker habitat improvement. 

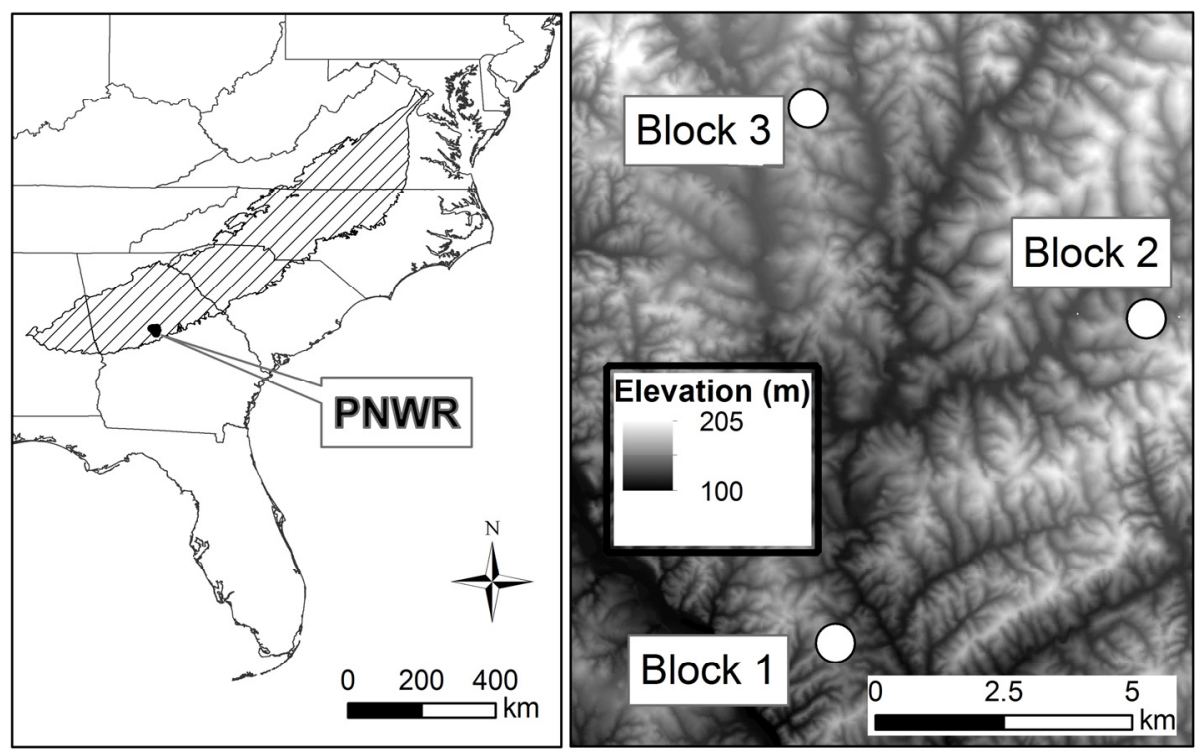

Figure 1. Location of the study site and three blocks within the Piedmont National Wildlife Refuge near Macon, Georgia, USA.

Similar to most of the southeastern Piedmont region, upland forests of the PNWR are dominated by second and third growth mixed pine-hardwood forests that established after agricultural abandonment. The pine component is mostly loblolly pine with some shortleaf pine (Pinus echinata Miller). The hardwood component is diverse and consists of two major groups: mesic hardwoods and upland hardwoods. Mesic hardwood species include sweetgum (Liquidambar styraciflua L.), red maple (Acer rubrum L.), winged elm (Ulmus alata Michaux), and tulip poplar (Liriodendron tulipifera L.). Mesic hardwood species in the midstory include Florida maple (Acer barbatum Michaux), dogwood (Cornus florida L.), and persimmon (Diospyros virginiana L.). Upland hardwood species include oaks and hickories such as white oak (Quercus alba L.), southern red oak (Quercus falcata Michaux), post oak (Quercus stellata Wang), mockernut hickory (Carya tomentosa Nuttall), and pignut hickory (Carya glabra Miller). Nomenclature follows Radford et al. [37].

\subsection{Study Design}

The study consisted of three sites which served as blocking units, each with a series of eight plots approximately one hectare in size. Individual blocks varied in overstory structure and composition as well as disturbance history. Basal area in all blocks was composed primarily of loblolly pine but each differed in the amount of oak-hickory and mesic hardwoods (Figure S1). Block 1 had not experienced fire since at least prior to 1980. Blocks 2 and 3 were burned once in the early 1980s and once in the early 1990s, with the exception of two plots.

Two plots within each block were randomly assigned treatments and scheduled to be burned biennially for eight years within one of four six-week windows between early April and the middle of September (Table 1). The windows roughly correspond to late spring (1 April to 12 May), early summer (13 May to 25 June), mid-summer (26 June to 6 August), and late summer (8 August to 18 September). Managers were unable to burn according to schedule due to drought and four burns were postponed from 2000 to 2001 and two burns occurred outside their assigned window. These deviations resulted in a few systematic biases. All plots assigned to burn in late spring were burned four times, while those assigned to late summer were burned only three times (and one plot only twice). In addition, both burns that occurred outside of their given range of dates were supposed to be early summer burns.

All fires were lit as strip-head fires that burned as low intensity surface fires. Burning conditions varied but relative humidity was generally $45 \%-80 \%$ with temperatures of $21-32{ }^{\circ} \mathrm{C}$. Fires generally 
top-killed shrubs and consumed $>90 \%$ of the vegetation in the understory. Flame lengths generally averaged below $0.5 \mathrm{~m}$.

Table 1. Burn windows and dates of growing season prescribed fires in the Piedmont National Wildlife Refuge near Macon, Georgia, USA. Dates are represented as Month/Day.

\begin{tabular}{|c|c|c|c|c|c|}
\hline Block & & $\begin{array}{l}\text { Late Spring } \\
(4 / 1 \text { to } 5 / 12)\end{array}$ & $\begin{array}{l}\text { Early Summer } \\
(5 / 13 \text { to } 6 / 25)\end{array}$ & $\begin{array}{l}\text { Mid Summer } \\
(6 / 26 \text { to } 8 / 6)\end{array}$ & $\begin{array}{l}\text { Late Summer } \\
(8 / 7 \text { to } 9 / 18)\end{array}$ \\
\hline \multirow[t]{6}{*}{ Block 1} & 1998 & $4 / 2,4 / 27$ & $5 / 13,6 / 9$ & $7 / 29,7 / 29$ & $8 / 24,9 / 9$ \\
\hline & 2000 & $4 / 5,4 / 26$ & $7 / 26^{1}$ & $7 / 26$ & \\
\hline & 2001 & & $6 / 7$ & $7 / 12$ & $9 / 18,9 / 18$ \\
\hline & 2002 & $4 / 16,5 / 7$ & $5 / 15,6 / 5$ & $8 / 1$ & \\
\hline & 2003 & & & $6 / 26$ & $9 / 10$ \\
\hline & 2004 & $4 / 15,4 / 29$ & $5 / 24$ & $8 / 4$ & \\
\hline \multirow[t]{6}{*}{ Block 2} & 1998 & $4 / 2,4 / 27$ & $5 / 13,6 / 8$ & $7 / 21,7 / 21$ & $8 / 11,9 / 8$ \\
\hline & 2000 & $4 / 5,4 / 26$ & $7 / 25^{1}$ & $7 / 25$ & \\
\hline & 2001 & & $6 / 6$ & $7 / 12$ & $9 / 18,9 / 18$ \\
\hline & 2002 & $4 / 16,5 / 7$ & $5 / 15,6 / 5$ & $8 / 1$ & \\
\hline & 2003 & & & $6 / 26$ & $9 / 10,9 / 10$ \\
\hline & 2004 & $4 / 19,4 / 29$ & $5 / 24$ & $8 / 4$ & \\
\hline \multirow[t]{6}{*}{ Block 3} & 1998 & $4 / 2,4 / 25$ & $5 / 13,6 / 8$ & $7 / 22,8 / 4$ & $8 / 24,9 / 8$ \\
\hline & 2000 & $4 / 16,5 / 8$ & $5 / 15$ & $7 / 23$ & \\
\hline & 2001 & & $6 / 5$ & $7 / 9$ & $9 / 17,9 / 17$ \\
\hline & 2002 & $4 / 16,5 / 8$ & $5 / 15,6 / 4$ & $8 / 1$ & \\
\hline & 2003 & & & $6 / 26$ & $8 / 28,8 / 28$ \\
\hline & 2004 & $4 / 19,4 / 29$ & $5 / 24$ & $8 / 4$ & \\
\hline
\end{tabular}

\subsection{Field Sampling}

One circular 0.08 ha plot was located in the center of each treatment plot and all trees $>11.7 \mathrm{~cm}$ $\mathrm{dbh}$ (diameter at breast height) were identified to species and measured at the beginning of the study in 1997 and again at the end in 2005. In addition, a $30.5 \mathrm{~m}$ transect was established on an upper slope in each plot. At the midway point, all saplings (woody stems $0.25-11.6 \mathrm{~cm}$ dbh) within a radius of $5.1 \mathrm{~m}\left(81.7 \mathrm{~m}^{2}\right)$ were identified to species and dbh was measured in 1997, 2001, and 2005.

\subsection{Data Analysis}

We used a one-way repeated measures ANOVA to look at the effects of repeated burning and among seasonal burn window treatments on aspects of forest structure in the overstory and midstory. We chose to use an alpha level of $\alpha=0.05$ to control for the potential to inflate Type I error due to the large number of dependent variables we were interested in testing. We chose a simple repeated measures ANOVA over other uni- and multivariate approaches in order to maximize the power of our tests since we had only three replicates for window of burn [38]. In instances where the assumption of circularity in the covariance matrix was not met, probability levels for F-Tests were adjusted using the more conservative Geisser-Greenhouse method [39]. The Tukey-Kramer multiple comparison test was used for post-hoc comparisons.

Analysis of overstory tree data included changes in stand density, basal area, and quadratic mean diameter of all trees and species groups between years (1997-2005) and windows. Species groups included pine, mesic hardwoods, and oak-hickory (see study site description for species composition of each group). The second analysis included the density of all saplings and species groups between years $(1997,2001$, and 2005) and burn windows. 


\section{Results}

\subsection{Saplings}

The density of all saplings decreased significantly over time (Table 2, Figure 2a). Most of the sapling component was made up of mesic hardwoods which also decreased significantly over both time periods $(p<0.00001)$ (Figure 2a). Pines decreased significantly $(p=0.021)$ between 1997 and 2001 but there was no significant difference between 2001 and 2005. There were no significant differences in density between years for oak-hickory saplings.

Results also revealed compositional differences among blocks (Table 2, Figure 2b). These included all saplings: $(p=0.036)$, pine $(p=0.0067)$, oak hickory $(p=0.005)$, and mesic hardwoods $(p=0.014)$ (Figure $2 b)$. Differences in pine saplings among blocks was highly significant $(p=0.0067)$. No significant differences were found among windows, but there was significant three-way interaction between time, block, and window for all saplings $(p=0.021)$ and pine $(p=0.038)$.

Table 2. Analysis of Variance for effects of repeated growing season burn effects on sapling density over time, block, and timing of burn window (Win) in mixed pine-hardwood forests of the Piedmont National Wildlife Refuge near Macon, Georgia, USA. $p$-values $\leq 0.05$ are noted with an * Greenhouse-Geisser adjusted $p$-values (GG) are given for those repeated measures data that did not meet circularity assumptions.

\begin{tabular}{|c|c|c|c|c|c|c|c|}
\hline $\begin{array}{l}\text { Sapling } \\
\text { Density }\end{array}$ & $\begin{array}{l}\text { Time } \\
(\mathrm{df}=2)\end{array}$ & $\begin{array}{c}\text { Block } \\
(\mathrm{df}=2)\end{array}$ & $\begin{array}{c}\text { Time*Block } \\
(\mathrm{df}=4)\end{array}$ & $\begin{array}{c}\text { Win } \\
(\mathrm{df}=3)\end{array}$ & $\begin{array}{l}\text { Time*Win } \\
(\mathrm{df}=6)\end{array}$ & $\begin{array}{l}\text { Block*Win } \\
(\mathrm{df}=6)\end{array}$ & $\begin{array}{c}\text { Time }^{*} \text { Block }^{*} \text { Win } \\
(\mathrm{df}=12)\end{array}$ \\
\hline \multirow{2}{*}{ All } & $F=49.5$ & $F=4.44$ & $F=1.9$ & $F=1.82$ & $F=1.04$ & $F=1.53$ & $F=2.63$ \\
\hline & $\mathrm{GG}=0.0000^{*}$ & $p=0.036^{*}$ & $\mathrm{GG}=0.152$ & $p=0.197$ & $\mathrm{GG}=0.423$ & $p=0.49$ & $\mathrm{GG}=0.021^{*}$ \\
\hline \multirow{2}{*}{ Pine } & $F=7.00$ & $F=7.81$ & $F=5.16$ & $F=2.15$ & $F=1.81$ & $F=2.68$ & $F=2.32$ \\
\hline & $\mathrm{GG}=0.021^{*}$ & $p=0.0067^{*}$ & $\mathrm{GG}=0.024^{*}$ & $p=0.147$ & $\mathrm{GG}=0.198$ & $p=0.069$ & $\mathrm{GG}=0.038^{*}$ \\
\hline Oak & $F=3.1$ & $F=8.73$ & $F=1.75$ & $F=1.88$ & $F=0.70$ & $F=1.77$ & $F=0.95$ \\
\hline Hickory & $\mathrm{GG}=0.1$ & $p=0.005^{*}$ & $\mathrm{GG}=0.2$ & $p=0.19$ & $\mathrm{GG}=0.59$ & $p=0.19$ & $\mathrm{GG}=0.5$ \\
\hline Mesic & $F=36.35$ & $F=6.25$ & $F=2.67$ & $F=2.32$ & $F=2.02$ & $F=1.56$ & $F=1.62$ \\
\hline Hardwood & $p=0.0000^{*}$ & $p=0.014^{*}$ & $p=0.06$ & $p=0.13$ & $p=0.1$ & $p=0.24$ & $p=0.15$ \\
\hline
\end{tabular}

a)

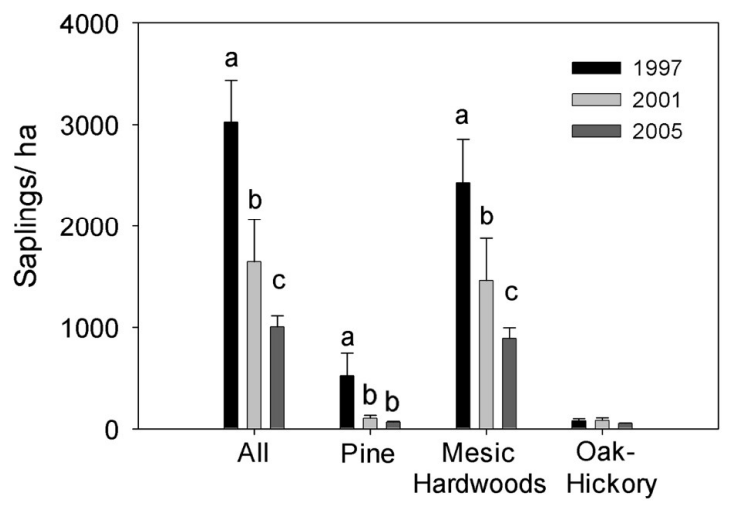

b)

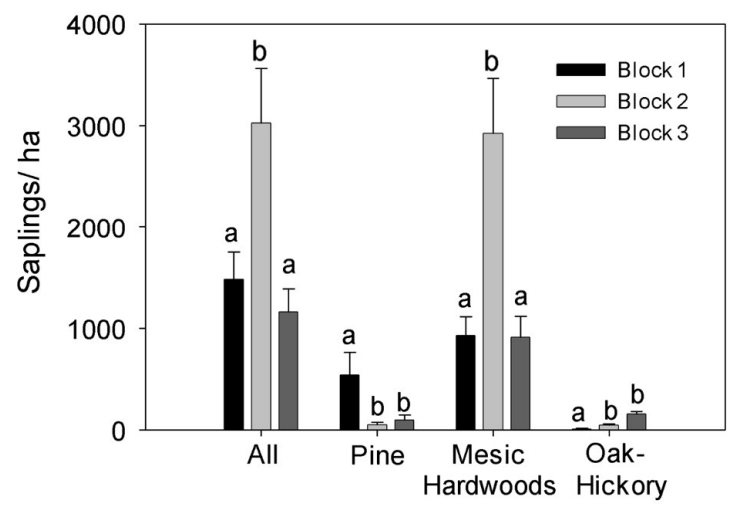

Figure 2. Effects of repeated growing season prescribed fire on density of saplings $(0.25$ to $11.6 \mathrm{~cm}$ $\mathrm{dbh}$ ) (a) over time and (b) by block in mixed pine-hardwood forests of the Piedmont National Wildlife Refuge near Macon, Georgia, USA. Letters represent significant differences $(p \leq 0.05)$ for post hoc Tukey's Tests on the main effect of time between 1997, 2001, and 2005. 


\subsection{Overstory Trees}

There was little change over time in basal area of all trees or species groups between 1997 and 2005 (Figure 3, Table 3). Basal area of all trees increased only slightly from $24.6 \mathrm{~m}^{2} \mathrm{ha}^{-1}$ in 1997 to $25.1 \mathrm{~m}^{2} \mathrm{ha}^{-1}$ in 2005 (Figure 3a). Density of all trees decreased significantly $(p=0.03$ ) from 440.9 to 395.7 trees ha ${ }^{-1}$ (Figure 3b). Density of pine trees also decreased significantly $(p=0.012)$ from 265.5 to 228 trees $\mathrm{ha}^{-1}$. Quadratic mean diameter of all trees increased significantly $(p<0.001)$ from 27.2 to $28.9 \mathrm{~cm}$ (Figure 3c). Quadratic mean diameter of pines also increased significantly $(p<0.001)$ from 32.1 to $34.3 \mathrm{~cm}$.

Differences in overstory forest structure and composition among blocks were significant $(p \leq 0.05)$ (Table 3). Attributes of forest structure with significant differences included basal area $(p=0.05)$ and density ( $p=0.04$ ) of all trees, which were both greatest in Block 3 and lowest in Block 1 (Figure S1). Mesic hardwood abundance was also highest in Block 3 and lowest in Block 1, and significant differences among blocks included basal area $(p=0.02)$, quadratic mean diameter $(p=0.019)$, and density $(p=0.03)$ (Figure S1).

Table 3. Analysis of Variance table for effects of repeated growing season burn effects on overstory structure and composition over time, block, and timing of burn window (Win) in mixed pine-hardwood forests of the Piedmont National Wildlife Refuge near Macon, Georgia, USA. Quadratic mean diameter is abbreviated by QMD. $p$-values $\leq 0.05$ are noted with an *. Greenhouse-Geisser adjusted $p$-values (GG) are given for those repeated measures data that did not meet circularity assumptions.

\begin{tabular}{|c|c|c|c|c|c|c|c|}
\hline $\begin{array}{c}\text { Structure/ } \\
\text { Composition }\end{array}$ & $\begin{array}{l}\text { Time } \\
(\mathrm{df}=1)\end{array}$ & $\begin{array}{l}\text { Block } \\
(\mathrm{df}=2)\end{array}$ & $\begin{array}{l}\text { Time*Block } \\
(\mathrm{df}=2)\end{array}$ & $\begin{array}{c}\text { Win } \\
(\mathrm{df}=3)\end{array}$ & $\begin{array}{c}\text { Time*Win } \\
(\text { df }=3)\end{array}$ & $\begin{array}{l}\text { Block* Win } \\
(\mathrm{df}=6)\end{array}$ & $\begin{array}{c}\text { Time }^{*} \text { Block }{ }^{*} \text { Win } \\
(\mathrm{df}=6)\end{array}$ \\
\hline Basal Area & $\begin{array}{l}F=0.57 \\
p=0.46\end{array}$ & $\begin{array}{l}F=4.06 \\
p=0.05^{*}\end{array}$ & $\begin{array}{l}F=0.1 \\
p=0.9\end{array}$ & $\begin{array}{c}F=1.07 \\
p=0.4\end{array}$ & $\begin{array}{l}F=0.77 \\
p=0.53\end{array}$ & $\begin{array}{l}F=0.71 \\
p=0.65\end{array}$ & $\begin{array}{l}F=0.45 \\
p=0.83\end{array}$ \\
\hline PineBasal Area & $\begin{array}{l}F=0.32 \\
p=0.58\end{array}$ & $\begin{array}{l}F=1.16 \\
p=0.35\end{array}$ & $\begin{array}{l}F=0.24 \\
p=0.79\end{array}$ & $\begin{array}{l}F=1.00 \\
p=0.43\end{array}$ & $\begin{array}{l}F=0.27 \\
p=0.84\end{array}$ & $\begin{array}{l}F=0.21 \\
p=0.97\end{array}$ & $\begin{array}{l}F=0.56 \\
p=0.76\end{array}$ \\
\hline $\begin{array}{l}\text { Oak-Hickory } \\
\text { Basal Area }\end{array}$ & $\begin{array}{l}F=0.28 \\
p=0.61\end{array}$ & $\begin{array}{l}F=0.93 \\
p=0.42\end{array}$ & $\begin{array}{l}F=1.05 \\
p=0.38\end{array}$ & $\begin{array}{l}F=1.43 \\
p=0.28\end{array}$ & $\begin{array}{l}F=0.63 \\
p=0.61\end{array}$ & $\begin{array}{l}F=0.98 \\
p=0.48\end{array}$ & $\begin{array}{l}F=2.13 \\
p=0.12\end{array}$ \\
\hline $\begin{array}{c}\text { Mesic Hardwood } \\
\text { Basal Area }\end{array}$ & $\begin{array}{l}F=3.01 \\
p=0.36\end{array}$ & $\begin{array}{l}F=5.54 \\
p=0.02^{*}\end{array}$ & $\begin{array}{c}F=0.54 \\
p=0.6\end{array}$ & $\begin{array}{c}F=1.81 \\
p=0.2\end{array}$ & $\begin{array}{l}F=3.44 \\
p=0.05^{*}\end{array}$ & $\begin{array}{c}F=4.54 \\
p=0.013^{*}\end{array}$ & $\begin{array}{l}F=0.42 \\
p=0.85\end{array}$ \\
\hline Density & $\begin{array}{l}F=6.45 \\
p=0.03^{*}\end{array}$ & $\begin{array}{l}F=4.47 \\
p=0.04^{*}\end{array}$ & $\begin{array}{l}F=0.29 \\
p=0.76\end{array}$ & $\begin{array}{l}F=1.79 \\
p=0.20\end{array}$ & $\begin{array}{l}F=0.43 \\
p=0.73\end{array}$ & $\begin{array}{l}F=0.64 \\
p=0.70\end{array}$ & $\begin{array}{l}F=0.72 \\
p=0.64\end{array}$ \\
\hline Pine Density & $\begin{array}{c}F=8.72 \\
p=0.012^{*}\end{array}$ & $\begin{array}{l}F=0.96 \\
p=0.41\end{array}$ & $\begin{array}{l}F=1.12 \\
p=0.36\end{array}$ & $\begin{array}{l}F=1.36 \\
p=0.30\end{array}$ & $\begin{array}{l}F=0.81 \\
p=0.51\end{array}$ & $\begin{array}{l}F=0.36 \\
p=0.89\end{array}$ & $\begin{array}{l}F=1.02 \\
p=0.46\end{array}$ \\
\hline $\begin{array}{l}\text { Oak-Hickory } \\
\text { Density }\end{array}$ & $\begin{array}{l}F=0.05 \\
p=0.82\end{array}$ & $\begin{array}{l}F=1.22 \\
p=0.33\end{array}$ & $\begin{array}{l}F=1.32 \\
p=0.30\end{array}$ & $\begin{array}{l}F=1.65 \\
p=0.23\end{array}$ & $\begin{array}{l}F=0.05 \\
p=0.98\end{array}$ & $\begin{array}{l}F=0.64 \\
p=0.69\end{array}$ & $\begin{array}{l}F=1.11 \\
p=0.41\end{array}$ \\
\hline $\begin{array}{l}\text { Mesic Hardwood } \\
\text { Density }\end{array}$ & $\begin{array}{l}F=2.25 \\
p=0.16\end{array}$ & $\begin{array}{l}F=4.79 \\
p=0.03^{*}\end{array}$ & $\begin{array}{l}F=0.06 \\
p=0.94\end{array}$ & $\begin{array}{l}F=2.84 \\
p=0.08\end{array}$ & $\begin{array}{l}F=2.46 \\
p=0.11\end{array}$ & $\begin{array}{l}F=3.47 \\
p=0.03^{*}\end{array}$ & $\begin{array}{l}F=1.22 \\
p=0.36\end{array}$ \\
\hline QMD & $\begin{array}{l}F=24.02 \\
p<0.001^{*}\end{array}$ & $\begin{array}{l}F=0.70 \\
p=0.52\end{array}$ & $\begin{array}{l}F=0.92 \\
p=0.43\end{array}$ & $\begin{array}{l}F=0.41 \\
p=0.75\end{array}$ & $\begin{array}{l}F=0.51 \\
p=0.68\end{array}$ & $\begin{array}{l}F=0.40 \\
p=0.87\end{array}$ & $\begin{array}{l}F=0.55 \\
p=0.76\end{array}$ \\
\hline Pine QMD & $\begin{array}{c}F=36.1 \\
p<0.001^{*}\end{array}$ & $\begin{array}{l}F=0.50 \\
p=0.62\end{array}$ & $\begin{array}{l}F=1.72 \\
p=0.22\end{array}$ & $\begin{array}{l}F=0.45 \\
p=0.72\end{array}$ & $\begin{array}{l}F=0.37 \\
p=0.78\end{array}$ & $\begin{array}{l}F=0.36 \\
p=0.89\end{array}$ & $\begin{array}{l}F=0.47 \\
p=0.82\end{array}$ \\
\hline $\begin{array}{c}\text { Oak-Hickory } \\
\text { QMD }\end{array}$ & $\begin{array}{l}F=0.06 \\
p=0.82\end{array}$ & $\begin{array}{l}F=3.13 \\
p=0.08\end{array}$ & $\begin{array}{l}F=0.04 \\
p=0.96\end{array}$ & $\begin{array}{l}F=1.56 \\
p=0.25\end{array}$ & $\begin{array}{l}F=1.39 \\
p=0.29\end{array}$ & $\begin{array}{l}F=0.78 \\
p=0.60\end{array}$ & $\begin{array}{c}F=3.81 \\
p=0.023^{*}\end{array}$ \\
\hline $\begin{array}{c}\text { Mesic Hardwood } \\
\text { QMD }\end{array}$ & $\begin{array}{l}F=3.13 \\
p=0.102\end{array}$ & $\begin{array}{l}F=5.57 \\
p=0.02^{*}\end{array}$ & $\begin{array}{l}F=0.01 \\
p=0.99\end{array}$ & $\begin{array}{c}F=31.9 \\
p<0.001^{*}\end{array}$ & $\begin{array}{l}F=0.33 \\
p=0.80\end{array}$ & $\begin{array}{l}F=27.71 \\
p<0.001^{*}\end{array}$ & $\begin{array}{l}F=0.47 \\
p=0.82\end{array}$ \\
\hline
\end{tabular}

There were no differences among burning windows for density or basal area of all trees or species groups (Table 3). Mesic hardwoods' quadratic mean diameter differed among windows $(p<0.001)$, but there was a significant block by window interaction $(p<0.001)$ (Table 3). Significant two-way interactions included time and window for mesic hardwood basal area $(p=0.05)$, block and window for mesic hardwood basal area $(p=0.013)$ and density $(p=0.03)$. Three-way interactions among time, block, and window for oak-hickory quadratic mean diameter were also significant $(p=0.023)$. These results suggest a large degree of variation in composition (particularly abundance of mesic hardwoods) among windows. 
a)

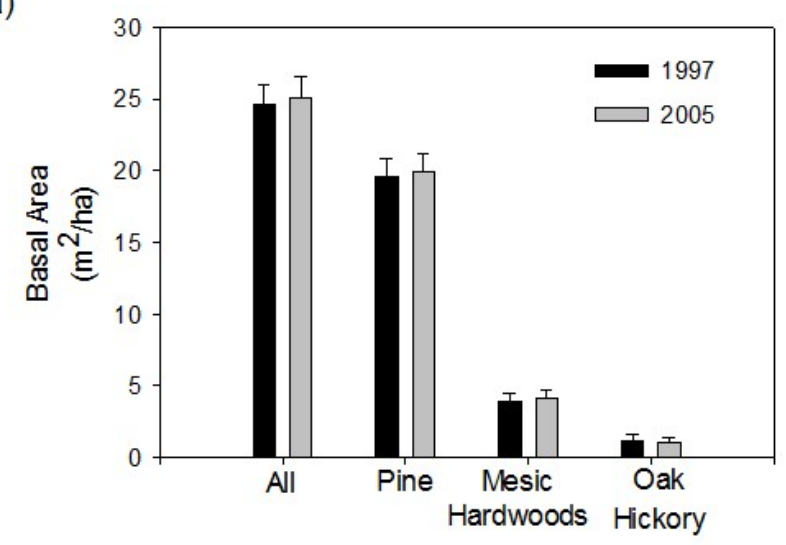

b)

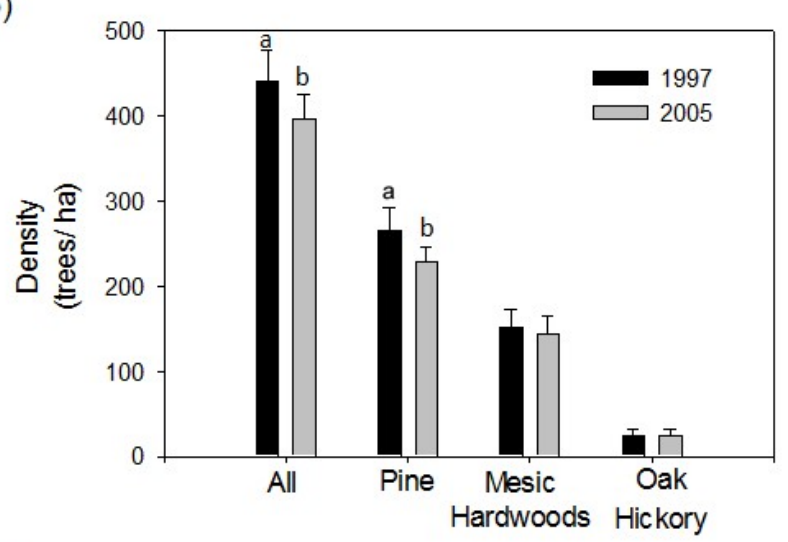

c)

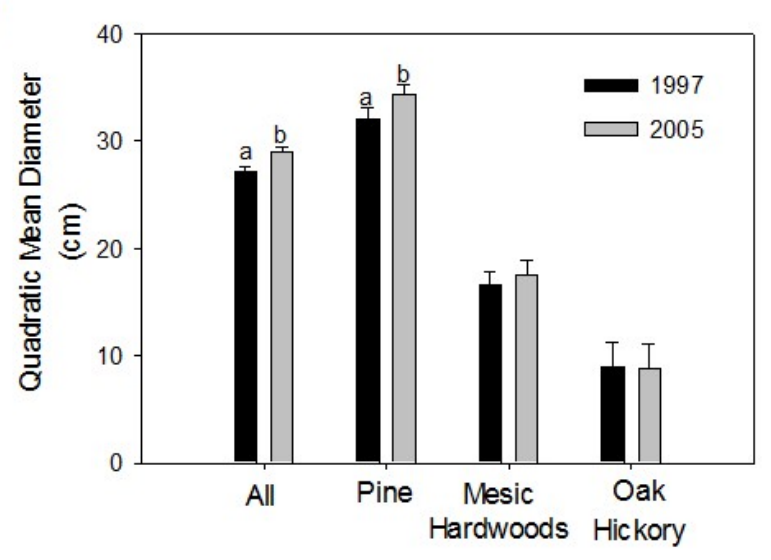

Figure 3. Effects of repeated growing season prescribed fire on (a) basal area, (b) density, and (c) quadratic mean diameter of overstory trees $(\geq 11.7 \mathrm{~cm})$ in mixed pine-hardwood forests of the Piedmont National Wildlife Refuge near Macon, Georgia, USA. Letters represent significant differences $(p \leq 0.05)$ for post hoc Tukey's Tests on the main effect of time between 1997 and 2005.

\section{Discussion}

Our results agree with early work in the southeastern Piedmont that the most consistent and readily observable effect of fire is an immediate reduction in density of saplings and smaller trees [26-29]. However, our results also demonstrate that repeated burning can be effective at maintaining and even furthering initial decreases in midstory density. Differential responses among species groups suggest minor compositional changes, specifically the loss of some smaller pine trees and saplings and mesic hardwood saplings in the midstory, but changes in overstory trees $>11.7 \mathrm{~cm}$ 
dbh were limited. Overall, we found little evidence to suggest that repeated burning during different time periods within the growing season resulted in different structural or compositional changes.

\subsection{Effects on Midstory Saplings}

While other studies in the region have reported net increases in hardwood saplings after single or few burns $[28,30,31]$, our results suggest that three or four burns may effectively reduce sapling density. These results are consistent with Dey and Hartman [40] who found that the probability of surviving a fire decreases with increasing number of burns for many of the species in our study. Differences between pines and hardwoods were apparent and related to the ability to re-sprout following top-kill. In Block 1 where density was initially high, pine saplings were reduced by almost four times between 1997 and 2001, followed by only a minor reduction at the final sampling period. Mesic hardwood saplings, the most abundant group, declined at a similar rate over both time periods but final densities were still relatively high ( $\sim 800$ stems/ha) as a result of sprouting. Although the least abundant, oak-hickory saplings were also maintained by re-sprouting and appear to be the most resilient as repeated burning did little to reduce sapling density except in Block 1. While continued burning at frequencies of 2 to 3 years would likely maintain lower densities of saplings, evidence from the coastal plain suggests that annual burning would be required to entirely eliminate sprouting hardwoods [20].

\subsection{Effects on Overstory Trees}

Repeated growing season fires had very little effect on the structure of overstory trees. Despite a slight increase in the quadratic mean diameter, there was very little change in density and basal area. Any losses of basal area to mortality were evidently offset by growth of surviving trees. Significant decreases in quadratic mean diameter of all trees and pines alone suggest some mortality of smaller pine trees, but it is unlikely that fire alone accounts for the observed changes. Past work has shown that low intensity fires such as those in this study rarely kill loblolly pines $\geq 11.7 \mathrm{~cm}$ dbh [41-43]. Instead, slight changes in density and quadratic mean diameter are most likely the result of density-dependent mortality of smaller, suppressed pines. Mortality of smaller pines may be related to self- thinning (e.g., Peet and Christensen [44]) that may have been accelerated by fire and drought during the study period. Assessing the relative contribution of burning and drought to observed dynamics is difficult, however, especially without unburned controls.

Mesic hardwoods and species of oak-hickory showed very little evidence of change compared to loblolly pine, and our results are consistent with other studies that found little effect of fire on hardwood species $\geq 11.7 \mathrm{~cm}$ dbh $[26,45]$. Once hardwood establish and reach this size, it appears unlikely that low intensity fire will be sufficient to affect composition of these species. Some species of mesic hardwoods may be less susceptible to suppression and thinning because they are more shade tolerant (e.g., red maple, Florida maple, and flowering dogwood), while oaks may be more tolerant of drought [46]. Although our results suggest that repeated burning may have little short-term effect on overstory structure and composition, lack of recruitment into smaller size classes from the decreased sapling pool may result in longer-term changes with continued application of prescribed fire.

\subsection{Timing of Growing Season Burn}

Past studies on the effects of seasonality and timing of burn have been limited due to confounding variables and problems in experimental design [18]. Likewise, this study has some experimental flaws primarily due to difficulties in following the original burn schedule. Despite these issues, we found little evidence to suggest that time of burn within the growing season affects forest structure or composition in the understory after three or four repeated fires have been applied. Our results provide little evidence to support differential effects of burn timing after eight years, but do not necessarily discount the potential importance of growing season burn window which may have longer term consequences or interact with reproduction of individual species. 


\subsection{Management Considerations}

One of the foremost goals of burning on public land in the Piedmont of the southeastern US is the promotion of habitat for red-cockaded woodpeckers which are strongly associated with open park-like pine savannahs with little woody vegetation in the midstory. Woodpecker cluster stands in loblolly/shortleaf pine forests generally have basal areas between 9-14 $\mathrm{m}^{2} \mathrm{ha}^{-1}$ [22] with less than $3 \mathrm{~m}^{2} /$ ha of the total being hardwood [23]. Given the lack of overstory change observed in this study, our data suggest that repeated growing season burns alone are insufficient to establish suitable habitat for red-cockaded woodpeckers in an eight-year period. Basal area in our plots was still more than twice that recommended for woodpecker habitat. Controlling woody vegetation in the midstory is also of particular importance as birds will abandon cluster sites when midstory basal area reaches $5 \mathrm{~m}^{2} /$ ha [24,25]. Although burning has the potential to eliminate saplings and prevent recruitment into the midstory, mechanical thinning would be necessary to reduce basal area, particularly that of mesic hardwoods, to promote suitable habitat.

The lack of structural change after repeated fire suggests very low intensity of the growing season burns in the Piedmont region. A large contribution of mesic hardwood litter to live and dead fuels can decrease flammability of surface fuels [41] and limit fire intensity, hindering the ability of managers to achieve desired outcomes under an acceptable prescription. Even during drought conditions, relative humidity and fuel moisture in live vegetation may remain high during the growing season and more aggressive ignition techniques (i.e., headfires) may be required for greater success at reducing hardwood density. Other work on prescribed fire in the southeastern United States found that despite more drought-like conditions during the growing season, dormant season burns were higher in intensity due to lower amounts of live fuels and greater total fuel loads [47]. Thus, dormant season burns may also have greater potential to achieve desired management outcome.

\section{Conclusions}

Repeated growing season burns have the potential to alter forest structure in Piedmont forests by decreasing sapling density in the midstory, but low intensity fires such as the ones in our study result in little change in overstory structure and composition. A continued regime of frequent growing season burns may result in forest structure resembling Coastal Plain pine savannahs at longer time scales, but long-term compositional changes are unclear. Greater fire free intervals are necessary to allow for loblolly pine regeneration to attain a size capable of surviving fire but could allow for competing hardwoods to reach fire tolerant stature unless more fires can completely kill and eliminate sprouting individuals. Although we found no evidence that burning at different times throughout the growing season has differential effects on forests of the Piedmont region, we cannot discount the potential for differences in effects with more intense fires.

Supplementary Materials: The following are available on line at http://www.mdpi.com/1999-4907/6/1/8/s1, Figure S1: Differences among blocks in the effects of repeated growing season prescribed fire on (a) basal area, (b) density, and (c) block quadratic mean diameter of overstory trees ( $\geq 11.7 \mathrm{~cm} \mathrm{dbh})$ in mixed pine-hardwood forests of the Piedmont National Wildlife Refuge near Macon, Georgia, USA.

Acknowledgments: We would like to acknowledge Thomas Phillips, Jimmy Rickard, David Combs, Mike Allen, Mark Yates, and Bill O'Connell for conducting vegetation surveys throughout the duration of this project. Carl Schmidt and John Mason of the Piedmont National Wildlife Refuge were responsible for application of burn treatments. Funding was provided by U.S. Fish and Wildlife Service/Boise Interagency Fire Center.

Author Contributions: D.W. conceived, designed, and performed the experiments; M.R. and J.O'B. analyzed the data; M.R. wrote the paper and K.O. and J.O' B. advised throughout.

Conflicts of Interest: The authors declare no conflict of interest. 


\section{References}

1. Moore, M.M.; Wallace Covington, W.; Fule, P.Z. Reference conditions and ecological restoration: A southwestern ponderosa pine perspective. Ecol. Appl. 1999, 9, 1266-1277. [CrossRef]

2. Peterson, D.W.; Reich, P.B. Prescribed fire in an oak savanna: Fire frequency effects on stand structure and dynamics. Ecol. Appl. 2001, 11, 914-927. [CrossRef]

3. Sparks, J.C.; Masters, R.E.; Engle, D.M.; Bukenhofer, G.A. Season of burn influences fire behavior and fuel consumption in restored shortleaf pine-grassland communities. Rest. Ecol. 2002, 10, 714-722. [CrossRef]

4. Wade, D.D.; Brock, B.L.; Brose, P.H.; Grace, J.B.; Hoch, G.A.; Patterson, W.A. Fire in eastern ecosystems. In Wildland Fire in Ecosystems: Effects of Fire on Flora; GTR RMRS-42; Brown, J.K., Smith, J.K., Eds.; USDA forest Service, Rocky Mountain Research Station: Ogden, UT, USA, 2000.

5. McCaw, W.L. Managing forest fuels using prescribed fire-A perspective from southern Australia. For. Ecol. Manag. 2013, 294, 217-224. [CrossRef]

6. Govender, N.; Trollope, W.S.W.; Van Wilgen, B.W. The effect of fire season, fire frequency, rainfall and management on fire intensity in savannah vegetation in South Africa. J. Appl. Ecol. 2006, 43, 748-758. [CrossRef]

7. Fernandes, P.M.; Botehlo, H.S. A review of prescribed burning effectiveness in fire hazard reduction. Int. J. Wildland Fire 2003, 12, 117-128. [CrossRef]

8. Brockway, D.G.; Lewis, C.E. Long-term effects of dormant-season prescribed fire on plant community diversity, structure and productivity in a longleaf pine wiregrass ecosystem. For. Ecol. Manag. 1997, 96, 167-183. [CrossRef]

9. Elliott, K.J.; Hendrick, R.L.; Major, A.E.; Vose, J.M.; Swank, W.T. Vegetation dynamics after a prescribed fire in the southern Appalachians. For. Ecol. Manag. 1999, 114, 199-213. [CrossRef]

10. Ryan, K.C.; Knapp, E.E.; Varner, J.M. Prescribed fire in North American forests and woodlands: History, current practice, and challenges. Front. Ecol. Environ. 2013, 11, e15-e24. [CrossRef]

11. Knapp, E.E.; Estes, B.L.; Skinner, C.N. Ecological Effects of Prescribed Fire Season; a Literature Review and Synthesis for Managers; USDA Forest Service General Technical Report PSW-GTR-224; USDA Forest Service, Pacific Southwest Research Station: Albany, CA, USA, 2009.

12. Streng, D.R.; Glitzenstein, J.S.; Platt, W.J. Evaluating effects of season of burn in longleaf pine forests: A acritical literature and some results from an ongoing long-term study. In Proceedings of the Tall Timbers Fire Ecol. Conf. No. 18, Tallahassee, FL, USA, 30 May-2 June 1991; Tall Timbers Research Station: Tallahassee, FL, USA, 1993.

13. Glitzenstein, J.S.; Streng, D.R.; Platt, W.J. Evaluating Effects of Season of Burn on Vegetation in Longleaf Pine Savannahs; Final Report; Florida Game and Freshwater Fish Committee: Tallahassee, FL, USA, 1990.

14. Glitzenstein, J.S.; Platt, W.J.; Streng, D.R. Effects of fire regime and habitat on tree dynamics in north Florida longleaf pine savannas. Ecol. Monogr. 1995, 65, 441-476. [CrossRef]

15. De Groot, W.J.; Wein, R.W. Effects of fire severity and season of burn on Betula glandulosa growth dynamics. Int. J. Wildland Fire 2004, 13, 287-295. [CrossRef]

16. Kaufman, J.B.; Marin, R.E. Sprouting shrub response to different season and fuel consumption levels of prescribed fire in Sierra Nevada mixed conifer ecosystems. For. Sci. 1990, 36, 748-764.

17. Williams, R.J.; Cook, G.D.; Gill, A.M.; Moore, P.H.R. Fire regime, fire intensity and tree survival in a tropical savanna in northern Australia. Aust. J. Ecol. 1999, 24, 50-59.

18. Robbins, L.E.; Myers, R.L. Seasonal Effects of Prescribed Burning in Florida; Miscellaneous publication/Tall Timbers Research, Inc.: Tallahassee, FL, USA, 1992; Volume 8, pp. 1-97.

19. Stoddard, H.L. Use of controlled fire in southeastern upland game management. J. For. 1935, 33, $346-351$.

20. Waldrop, T.A.; Van Lear, D.H.; Lloyd, F.T.; Harms, W.R. Long-Term Studies of Prescribed Burning in Loblolly Pine Forests of the Southeastern Coastal Plain; USDA Forest Service General Technical Report SE-45; USDA Forest Service, Southeastern Forest Experiment Station: Asheville, NC, USA, 1987.

21. Reilly, M.J.; Waldrop, T.A.; O'Brien, J.J. Fuels management in the southern appalachian mountains, hot continental division. In Cumulative Watershed Effects of Fuel Management in the Eastern United States; USDA Forest Service General USDA Forest Service General Technical Report SRS-161; Southern Research Station: Asheville, NC, USA, 2012. 
22. Conner, R.N.; Snow, A.E.; O'Halloran, K.A. Red-cockaded woodpecker use of seedtree/shelterwood cuts in eastern Texas. Wildlife Soc. Bull. 1991, 19, 67-73.

23. Conner, R.N.; O'Halloran, K.A. Cavity-tree selection by red-cockaded woodpeckers as related to growth dynamics of southern pines. Wilson. Bull. 1987, 99, 398-412.

24. Conner, R.N.; Rudolph, D.C. Red-Cockaded Woodpecker Colony Status and Trends on the Angelina, Davy Crockett, and Sabine National Forests; USDA Forest Service Research Paper SO-250; Southern Forest Experimental Station: New Orleans, LA, USA, 1989.

25. Loeb, S.C.; Pepper, W.D.; Doyle, A.T. Habitat characteristics of active and abandoned Red-cockaded woodpecker colonies. South J. Appl. For. 1992, 16, 120-125.

26. Chaiken, L.E. The Behavior and Control of Understory Hardwoods in Loblolly Pine Stands; USDA Forest Service Research Tech. Note 72; Southern Forest Experimental Station: New Orleans, LA, USA, 1949.

27. Harrington, T.A.; Stevenson, G.K. Repeat burns reduce small stems in Texas Big Thicket. J. For. 1955, 53, 847.

28. Hodgkins, E.J. Effects of fire on undergrowth vegetation in upland southern pine forests. Ecology 1958, 39, 36-46. [CrossRef]

29. Brender, E.V.; Cooper, R.W. Prescribed burning in Georgia's Piedmont loblolly pine stands. J. For. 1968, 66, 31-36.

30. Oosting, H.J. The comparative effect of surface and crown fire on the composition of a loblolly pine community. Ecology 1944, 25, 61-69. [CrossRef]

31. Oosting, H.J.; Livingston, R.B. A resurvey of a loblolly pine community twenty-nine years after ground and crown fire. Bull. Torrey Bot. Club 1964, 91, 387-395. [CrossRef]

32. Wade, D.D.; Weise, D.; Shell, R. Some Effects of Periodic Winter Fire on Communities on the Georgia Piedmont, Proceedings of the 5th Biennial Southern Silvicultural Research Conference, Memphis, TN, USA, 1-3 November 1988; General Tech. Rep. SO-74; Dept. of Agriculture, Forest Service, Southern Forest Experiment Station: New Orleans, LA, USA, 1989.

33. Cook, E.R.; Meko, D.M.; Stahle, D.W.; Cleaveland, M.K. Drought reconstructions for the continental United States. J. Clim. 1999, 12, 1145-1162. [CrossRef]

34. USDA Soil Conservation Service and Forest Service. Soil Survey of Baldwin, Jones, and Putnam Counties, Georgia; USDA Soil Conservation Service and Forest Service: Washington, DC, USA, 1976.

35. Cowell, C.M. Presettlement Piedmont forests: Patterns in composition and disturbance in central Georgia. Ann. Assoc. Am. Geogr. 1995, 85, 65-83.

36. Guyette, R.P.; Stambaugh, M.C.; Dey, D.C.; Muzika, R.-M. Predicting fire frequency with chemistry and climate. Ecosystems 2012, 15, 322-335. [CrossRef]

37. Radford, A.E.; Ahles, H.E.; Bell, C.R. Manual of the Vascular Flora of the Carolinas; The University of North Carolina Press: Chapel Hill, NC, USA, 1968.

38. Scheiner, S.M. MANOVA: Multiple response variables and multispecies interactions. In The Design and Analysis of Ecological Experiments; Scheiner, S.M., Gurevitch, J., Eds.; Oxford University Press: New York, NY, USA, 2001; pp. 134-157.

39. Von Ende, C.N. Repeated-measures analysis: Growth and other time dependent measures. In The Design and Analysis of Ecological Experiments; Scheiner, S.M., Gurevitch, J., Eds.; Oxford University Press: New York, NY, USA, 2001; pp. 134-157.

40. Dey, D.C.; Hartman, G. Returning fire to Ozark Highland forest ecosystems: Effects on advance regeneration. For. Ecol. Manag. 2005, 217, 37-53. [CrossRef]

41. McNab, W.H. An overcrowded loblolly pine stand thinned with fire. South. J. Appl. For. 1977, 1, $24-26$.

42. Waldrop, T.A.; Lloyd, F.T. Precommercial thinning a sapling-sized loblolly pine stand with prescribed fire. South. J. Appl. For. 1988, 12, 203-207.

43. Wade, D.D. Thinning young loblolly pine stands with fire. Int. J. Wildland Fire 1993, 3, 169-178. [CrossRef]

44. Peet, R.K.; Christensen, N.L. Competition and tree death. Bioscience 1987, 37, 586-595. [CrossRef]

45. Lotti, T. Eliminating understory hardwoods with summer prescribed fires in Coastal Plain loblolly pine stands. J. For. 1956, 54, 191-192. 
46. Burns, R.M.; Honkala, B.H. Silvics of North America: 2. Hardwoods; Agricultural Handbook; USDA: Washington, DC, USA, 1990.

47. Kreye, J.K.; Varner, J.M.; Hiers, J.K.; Mola, J. Toward a mechanism for eastern North American forest mesophication: Differential litter drying across 17 species. Ecol. Appl. 2013, 23, 1976-1986. [CrossRef] [PubMed]

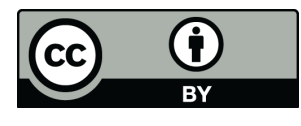

(C) 2016 by the authors; licensee MDPI, Basel, Switzerland. This article is an open access article distributed under the terms and conditions of the Creative Commons Attribution (CC-BY) license (http://creativecommons.org/licenses/by/4.0/). 